Jordaan, GJ

University of Pretoria

\title{
The contribution of the pioneer missionary, Reverend AJ Rousseau - 1925 to 1940 to the Dutch Reformed Church (DRC) mission in Sekhukhuneland ${ }^{1}$
}

\begin{abstract}
In this article the story of the pioneer missionary in Sekhukhuneland, Rev Abraham Rousseau is told. He was a missionary of the Dutch Reformed Church in Sekhukhuneland from 1926 to 1940 . This story deals with the preparation stage of Rousseau's work, the building of a parsonage, school, hostel, a small hospital and accommodation for the staff, and the expansion of the mission work as far as possible into Sekhukhuneland. Soon 21 outposts, including schools were established. Attention is given to the black evangelists who were the mission's fore-front workers. Attention is given to the relation between the white and black mission workers in the historical phase in which Rousseau played a role, and how these relations developed in later phases.
\end{abstract}

\section{INTRODUCTION}

Towards the end of the 20th century, David J Bosch 1991:7) stated "....we require a new vision to break out of the present stalemate toward a different kind of missionary involvement." He added that this did not mean that we have to jettison everything generations of Christians have done before us, that it would indeed be "... neither possible nor proper to attempt a revised definition of mission without taking a thorough look at the vicissitudes of missions and the missionary idea during the past twenty centuries of Christian church history" (p8).

At the beginning of the 21 st century, efforts that were undertaken in the 20th century to overcome the prevailing dualisms between different aspects of the life, work and faith has started to gather momentum. The term "integral mission" that is used by the Lausanne movement can be seen as part of this movement to understand the unity of the mission of the church: "The concept of 'integral mission' assisted the Lausanne movement to progress to a more comprehensive understanding of mission. 'Integral mission means discerning, proclaiming, and living out the Biblical truth that the gospel is God's good news, through the cross and resurrection of Jesus Christ, for individual persons, and for society, and for creation. All three are broken and suffering because of sin; all three are included in the redeeming love and mission of God; all three must be part of the comprehensive mission of Gods people"' (Lausanne III 2011:13) (Niemandt 2011:60).

In this article attention is given to the work of one missionary, Rev Abraham Rousseau. He was a missionary of the Dutch Reformed Church (DRC) in Sekhukhuneland from 1926 to 1940. An

\footnotetext{
1 This article is based on a PhD thesis, History of the DRC mission in Sekhukhuneland and Church development 1875 - 1994, that the writer completed at the Faculty of Theology, University of Pretoria, with dr AS van Niekerk of the Department Science of Religion and Missiology as study leader.
} 
NGTT Deel 54, Nommers $3 \& 4$, September en Desember 2013

effort is made, in the words of Bosch, “... to take a thorough look at the vicissitudes of missions and the missionary idea" of that time, as it finds expression in the work of a pioneer of the Dutch Reformed Church's mission in the area where the author of this article has served as a missionary from 1977. It is an effort by the author to understand his own living world better.

Attention will be given to the way in which the work of Rousseau was remembered and interpreted about half a century later in the congregation.

The work of Rousseau will be seen in the context of its time, and attention will be given to the way that the approach to mission has changed subsequently, with reference to the concept of "integral mission."

Lastly, the question will be asked what we can learn from his legacy in our search for an appropriate vision for mission in our times.

\section{ThE CONTEXT IN WHich ROUSSEAU WORKED}

In the $20^{\text {th }}$ century the Dutch Reformed Church (DRC) experienced a strong missionary movement that focused mostly on Southern Africa; there was a gradual increase of activities, a climax in the sixties and a dramatic decline since the seventies, as can be seen in the closing down of many missionary structures (van Niekerk 1997:408). Saayman (2007) divides the Dutch Reformed Mission into four waves: the early First Wave (1779 - 1834); the Second Wave (1867-1939) in which the church started to focus its mission on areas outside the then Cape Colony; the Third Wave (1954 - 1976) in which the mission of the church had to cross the borders between the white and black communities in the apartheid era, and the Fourth Wave, that started in 1990, where the church is searching for a way forward, and where it became popular to send missionaries to far away countries. Rousseau clearly stood within the Second Wave, and can be seen as a pioneer of the church's mission.

Rousseau served in the army of the "Zuid Afrikaanse Republiek" (the Republic of the Transvaal) during the Anglo-Boer War of 1899 - 1902. During the war he became gravely ill. He prayed to God to be healed and took an oath that if he was healed, he would return to the Pedi people of Sekhukhuneland as a missionary.

Rousseau was a good example of the way in which the missionary movement of the $20^{\text {th }}$ century in the DRC originated in the Anglo-Boer War, which played a prominent role in the Second Wave (Saayman 2007:57-62). The war led to a spiritual awakening in the church which found expression in a dedication to mission. According to Crafford (2982:144), many souls were led to introspection and repentance in the commandos and in the concentration- and prisoner of war camps that they saw as punishment of God. As the dedication to mission continued to grow deep into the second half of the century, it went through various phases and took on different forms. Kaboet, son of Rousseau, mentioned in a tape recording made by the author in 1977 that Rousseau stayed on the farm Eensgevonden near Nebo, together with other desolate farmers who were established in the area by the government after the Anglo-Boer War.

He left the farm to study theology at Wellington and was subsequently sent by the DRC to Nyasaland, now Malawi, where he worked for the next 15 years. In 1925 he responded positively to a call from the "Transvaalse Vroue Sendingvereniging" to start mission work in the area. After he had returned as missionary to the area, he initially lived on his own farm, Eensgevonden. His brother, Frikkie Rousseau, who owned the neighbouring farm, Weltevreden, now called 
NGTT: Oopbron - http://ngtt.journals.ac.za

Kgarathuthu, was already staying there before Rousseau was called. This whole area was called Zoetvelden.

The historian Herman Gilliomee wrote that, in the 1920's, Professor Johannes du Plessis supplied the framework for the idea that the DRC was in essence a missionary church with a broad social responsibility. This was before the rise of Afrikaner nationalism in the 1930's that led the DRC into political byways. The practice of separated churches, schools, and so on had existed long before that, but the term apartheid in its modern meaning first appeared in print in 1929, in a paper read by JC du Plessis (not Johannes du Plessis) at a mission conference of the DR Church of the Free State (see also Saayman 2007: 70). Until then, none of the DRC leaders propagated that the practice of separate schools and congregations be extended into separate political institutions. Johannes du Plessis, who is seen by Giliomee as the most authoritative voice in missions at the time, used every opportunity to oppose discrimination based on nationalism (Giliomee 2004:405, 408, 209).

Rousseau's work can well be described as missionary work with a broad social responsibility. He built churches, schools and a hospital. He continued the practice of his time of having separate schools for white and black children, but there is little evidence that he saw that in terms of political ideology, although nationally, Afrikaner nationalism was already growing. Neither did he get involved in strong opposition to racial discrimination, as Johannes du Plessis did.

\section{The preparation for mission wORK in SeKHUKHUnELAND}

The foreign mission work of the DRC of the Cape Synod was handed over to the 'Nederduitsch Hervormede of Gereformeerde Kerk van Suid-Afrika' in 1932. The first mission secretary was Rev D Theron (Keet 1942:197). The emerging movement received a strong impetus with the heightened involvement of the work of the 'Transvaal Vroue Sendingvereniging' in 1926.

In 1916 Rev A P Burger, who had a passion for Sekhukhuneland, together with Rev JHM Stofberg, requested the TVSV to send a missionary or evangelist to Secoecoens Mountain. The Executive Committee of the TVSV replied as follows:

\section{The Committee decided to request the TVSV (Transvaal Women's Mission Association) congress to maintain the salary of a missionary for Secoecoens Mountain, provided that the missionary should stay at the mountain with the people and that he must be able to speak their language - (author's own translation).}

Mrs HS Bosman, who was the chairperson of the congress, mentioned that it was interesting how the Bapedi people desired the white man's church, notwithstanding the fact that their chief was involved in a fearless battle with the ZAR government. The proposal of the committee was approved with a recommendation for a special collection (Louw 1972:14).

Mrs Bosman referred to the continuous tensions between chief Sekhukhune and the government. The DRC mission did not get involved in these conflicts, but developed good relations with several other chiefs, as well as with the government.

In 1923 the Portuguese government closed all mission stations in Portuguese East Africa. The same year Rev DTheron, the Mission Secretary of the DRC at that time, suggested that the Lord wanted them to concentrate on the thousands of indigenous people in their own country. He asked the ladies of the TVSV to take full responsibility for the mission in Sekhukhuneland. 
NGTT Deel 54, Nommers $3 \& 4$, September en Desember 2013

In 1923 the congress decided to establish a mission station at Nebo. Nebo is in Sekhukhuneland, and there were police and magistrate's offices. It was thought to be the ideal place for a mission station. At the next congress in Heidelberg, in 1924, the mission secretary reported that everything was in place and that the station would be erected under the auspices of the TVSV as soon as a missionary was available (Louw 1972:15).

\section{Reverend and Mrs AJ Rousseau were called to Sekhukhuneland}

With the reports tabled before them, the TVSV decided to call a full-time missionary to Sekhukhuneland. A call was made to Rev and Mrs AJ Rousseau, missionaries in Nyasaland (Malawi) in 1925. The Rousseau's' however, did not accept this calling.

Not long after this, the Rousseau's received a second call, and this time they seriously considered accepting. A nephew of Rousseau reminded him of a promise he had made to God during the Anglo-Boer War that he would enter the ministry and serve God in Sekhukhuneland, if he was healed from his illness. He accepted this call in 1925. He was inaugurated on 21 February 1926 at Ermelo as the first missionary of the TVSV in Sekhukhuneland (Crafford 1982:536).

According to Rousseau's son Kaboet, his father immediately erected a school for the children of the farm workers when he arrived at Eensgevonden in 1925. The Rousseau children attended school on the adjacent farm, Weltevreden. The school was built with soil and is still there.

The Nchabeleng brothers wrote as follows:

His children went to school at Weltevreden. At that time it was a school for white children only. Their children were Hellen, Kaboet, Joubert and Charlotte, two boys and two girls. They all studied Sepedi. Kaboet became director at the Lebowa Department of Education, Joubert became secretary for Bantu Education and Charlotte became a lecturer at the Setotolwane Teacher's Training College, and also taught at the Secondary School of Setotolwane. Since her marriage, Helen went to the white areas, and we do not know what happened to her. We heard that she also had a leadership post somewhere - (author's own translation).

\section{REPORTS TO THE TVSV}

At a presbytery meeting in Lydenburg, Rev GD Worst of Lydenburg pleaded that the new missionary, Rev Rousseau, should start his mission station at Maandagshoek, in the east, while Rev AP Burger of Middelburg pleaded for the western side of the Leolo Mountains. The presbytery's decision was to send the four missionaries in their service, Rev Bruwer, Rev van Schalkwyk, Rev Rousseau and Rev Maritz, to investigate the area in order to make a recommendation. They travelled by car to Rousseau's brother at Zoetvelden, from where they proceeded by ox-wagon. This story is told by Rev Maritz in his biography (1977:16). From Zoetvelden they undertook an extensive tour of the Leolo Mountain and the lower Olifants River to find a suitable location for a mission station. They recommended Mooiplaats, on the western side of the Leolo mountains on the Olifants River near Apel.

Rousseau reported in person to the delegates at a congress of the TVSV at Ermelo, held from 4 to 6 December 1926. He stated that the following denominations were also working in Sekhukhuneland: Lutheran, Wesleyan, Episcopal, Bapedi-Lutheran and the Ethiopian churches. He mentioned that some evangelists of the DRC had been working in the area for the past 20 years and reported that the Synodical Mission Commission had obtained a piece of land at Garatau near Maandagshoek with a view to starting a mission station. 
NGTT: Oopbron - http://ngtt.journals.ac.za

However, he decided not to use this property for a mission station, because Maandagshoek was in the eastern half, near Lydenburg. Secondly, the soil consisted of peat, which was not suitable for building. Close by was a large location where the Platinum Mine workers stayed at Maandagshoek. Rousseau mentioned the names of evangelist Johannes and McDonald Chitja, who were helping him at Garatau, Hoepakranz and Mankopaan (Louw 1972:16).

At the second Congress in 1927 Rousseau reported about his work at Garatau, Hoepakranz, Mankopaan, Eensgevonden, Zoetvelden, Korenkopjes and Masetleng.

In 1928 the TVSV bought Mooiplaats for $£ 2000$ (TVSB Ligpunte: 1975:19). In 1928 the Rousseau family moved from the farm Eensgevonden to Strydkraal B, which was closer to Mooiplaats, where he was still busy erecting the Burger mission station. Shortly afterwards, in 1929, they settled at the new mission station at Mooiplaats. The mission station was named Burger after Rev and Mrs A P Burger of Middelburg. The TVSV provided staff members to help the missionary with his ministry. The Nchabeleng brothers wrote:

Moruti Rousseau was a clever man and far-sighted. He was a short man but he walked fast like a man jumping. For this reason he was nicknamed 'Mpurankane', which means - 'he walks fast like one who is jumping' (author's own translation). ${ }^{2}$

Rousseau informed the Congress that he received no support from the European farmers in the area. He was also concerned about the low number of conversions: only six non-believers had been allowed to become members and be baptized. The old mother of the chief at Masetling also became a Christian. He mentioned that the Roman Catholic Church ${ }^{3}$ purchased 1600 morgen for $£ 5000$ ten miles away from the Anglicans. Immediately the Roman Catholics formed a working relationship with a medical doctor, as well as with teachers, nurses, agricultural workers and technical people. The DRC had none of these skilled workers and urged the congress to consider all options (Louw 1972:17).

\section{THE PIONEERING PHASE OF MISSION WORK - BURGER MISSION STATION AT MOOIPLAATS}

In 1929 the mission station Burger, named after Rev and Mrs A P Burger of the DRC Middelburg, was officially opened. The parsonage, a small church and a small hospital were in operation. Fruit trees were planted and a vegetable garden was established. The opening of the mission station was attended by several chiefs, church members and various guests. Major Hunt, the Native Commissioner, also wished them well. Rev Olivier and Rev Endemann took part as visiting missionaries. Since he was able to speak Northern Sotho, Rev Olivier took the lead. On Sunday morning he conducted a small service where Holy Communion was served to twelve European and six African believers (Louw 1972:17).

Rev and Mrs Rousseau, their four children, Sister Pietersen and Mr Schraader formed the official staff of Burger Mission Station. In 1929 Miss Bettie Schutte joined them as teacher. During 1930 to 1931 the following staff was added: Mr and Mrs Swart, as well as another teacher, Miss

2 The ZAR had farms allocated for white farmers but black people could buy any farm. In this case, the farm Mooiplaats was chosen for a mission station under the administration of the Native Commissioner. 3 The RCC mission station was called St Ritas' and the Anglican mission station was called Jane Furse. Fully equipped mission hospitals were run here for many years which later became government hospitals. 
NGTT Deel 54, Nommers $3 \& 4$, September en Desember 2013

Retha van der Merwe. A house was built for the evangelist and a corrugated building served as the girls' hostel and nurses' home.

\section{The BuRger misSiON SCHOOL}

There were 52 day children, while 22 adults attended the evening school at Burger. The school had a total of 57 pupils in 1932, but more than half of them were non-believers. Of the pupils $40 \%$ were baptized in other churches and only $10 \%$ belonged to the DRC. At the school, a Christian Youth movement was organized, which was attended by everyone, even the nonbelievers.

The Nchabeleng brothers wrote as follows:

Mr C N Phatudi was headmaster of this school until 1936. Hereafter he went to Marishane. This mission school went to Std 6 (VI) in reading, learning, singing and athletic practices. Schools which were linked were Mphahlele, Zebediela, Mohlatletse, Mothopong, Mafafe and Maandagshoek. From these schools came chief Stephen Phasha, chief Motodi Sekhukhune and Mr Salthiel Nchabeleng. Mr CN Phatudi married the daughter of Evangelist Mokwena, Miss Alice Mokwena. Mr ID Kgokolo of Mphahlele became principal of the mission school of Burger and after that he returned to Mphahlele to become the principal of the Community School of Mmutle - (author's own translation).

Mr CN (Cedric) Phatudi, who later became the prime minister of the homeland Lebowa, and his brother E M (Edward), who later became the moderator of the General Synod of the Dutch Reformed Church in Africa, were sons of chief Mmutle III, also knows as chief Phatudi III, the chief of Mphahlele.

Rousseau started a bursary fund for further training of children as teachers. He also started to make bricks in order to build a secondary school but this plan did not succeed. Eventually the bricks were taken to chief Sekhukhune where the Sekhukhune Secondary School was later erected. He also undertook to move all the children of Mothopong from the Berlin Mission to the Burger Mission; they came with their own food, plates and blankets. Many were motivated when they completed Std VI and he enabled them to study further at Stofberg Gedenkskool as teachers. One of them was Elder Motodi Salthiel Nchabeleng, who after Stofberg went to Lovedale to complete his studies. Others who followed him were Noah Nkgape Mashoene and Gad Mashupje Sekhukhune. Many followed their example like Mashabagole Benjamen Sekhukhune, Maria Ramaipadi, Virginia Maila, Mathulwe Silas Maila, Shadrack Mashoene, Joël Makantane Tsebane, Letsoalo Abram Nchabeleng, Rosina Mashoena, Reshoketšwe Mashoene, Esther Nchabeleng, Tryphosa Nchabeleng, Richard Moroaswi, Lazarus Ramaipadi, Enos Ramaipadi who became a minister and his brother an evangelist. Their sister married a Methodist minister. The Nchabeleng brothers report:

This initiative also later extended to Phaahla where Rebone Seloma and Ephraim Seloma became teachers and Phaahla-Mohlaka and Mogaladi became evangelists. Teachers like Dina Mashoene started a school at Phaahla and India and Magdalene Mashoene started a school at Strydkraal under the supervision of the church. She attended Stofberg in 1940 where they trained teachers, evangelists and ministers - (author's own translation). 
NGTT: Oopbron - http://ngtt.journals.ac.za

\section{BURgER CONGREGATION WAS REGISTERED IN FEBRUARY 1932}

Rousseau built a small hospital, a school and a parsonage at Strydkraal A. This became the mission station Burger.

The work developed sufficiently for a congregation, named Burger, to be registered in February 1932. This development allowed Rousseau and an elder to attend the first Mission Synod in March 1932 in Johannesburg as delegates (Louw 1972:19). They represented 120 members of the DRC Burger congregation. The December 1935 statistics were as follows: 175 members; 525 souls and 509 pupils in day schools (TVSV Congress 135:40).

\section{MedicAl Mission}

Sister van Schalkwyk was in charge of the hospital. From June to October 1932 a total of 1 219 patients were treated: 784 children under the age of 12; 298 women and 137 men. Most of the patients suffered from whooping cough, influenza, colds and other ailments, including malaria. The medical work was important in establishing good relationships with the community. The first medical doctor arrived in August 1934, but only stayed for three months. He was Dr Olden, a retired doctor who had earlier served as governor of the Seychelles (Kaboet Rousseau: tape-recording 1977). In 1935 Sister van Schalkwyk got married and was replaced by Sister Robbertze, who was very keen that a medical doctor should be appointed, but this only happened in 1938 with the appointment of Dr Le Roux.

Miss Maggie Mare became matron of the girl's hostel and Mr Gerrie Jansen started as a male nurse, assisting Dr Le Roux. Miss Maggie got married to Rev Conradie and Dr and Mrs Le Roux left. This was a serious blow to mission work in Sekhukhuneland. They were, however, replaced by Miss Wasserman and Miss van Rensburg as mission workers and Mr AD Fourie, a master builder, who renovated the buildings at the mission station. In February 1941 Miss Welham joined them as school principal, but left shortly afterwards to further her studies. Miss Wasserman joined the Sudan Mission (Louw 1972:20).

\section{EVANGELISTS WHO WORKED WITH ROUSSEAU}

WTN Hanekom wrote in 1976 that the writing of DRC history focused mainly on the European culture group. He criticized this narrow focus on one's own church ${ }^{4}$ (Crafford 1986:31). In a separate article I hope to bring some recognition to the story of the black pioneers. The names of the evangelists and the outposts where they were stationed are known. Their work is synonymous with the work of the missionaries in the pioneering missionary phase.

When Rousseau accepted the call to become the first missionary in Sekhukhuneland in 1925, some evangelists had already been working there for 20 years. From the mission station, Burger, he coordinated several mission schools and churches at the outposts. It was before the term "partnership in mission" was generally used in mission circles, but there was an element of partnership in the way Rousseau worked with the teachers and evangelists. Although personal details of these early pioneers are not available, their names should however be remembered. Together with the medical staff, these people were the friends of the missionaries. They were their co-workers and co-pioneers.

4 Hanekom's words as quoted by Crafford” “....kerkisties, ingestel op die eie (blanke) kultuurgroep en daarom eties en geografies ingeperk tot die geskiedskrywing van die eie kerk" 
NGTT Deel 54, Nommers $3 \& 4$, September en Desember 2013

The evangelists who worked with him were: McDonald Chitja at Garatau, Aäron Moraka at Gemsbokspruit, Silas Mohoje at Eensgevonden, Isak Khopochane at Buffelsfontein, Edward Mafanyolle at Gaataan, Alfonso Mokoena at Mankopaan and Willard Sefara and his wife at Mphahlele (Louw 1972:18).

There were about 21 outposts, many with schools. Outposts where no evangelists were posted included Hoepakranz in the village of Ngowe, which was situated on top of the Leolo Mountains, a climb of $3 \frac{1}{2}$ hours on foot. The village consisted of a group of fugitive Swazis who founded a place to stay here.

Korenkopjes is a farm situated about 10 kilometres from Eensgevonden. (Unfortunately this outpost, like many others, ceased to exist after Rousseau left. It was revived again in 1985 under the ministry of the Matlala mission Jordaan 2006:23).

Other outposts were Masetleng, Seseseo (1 $1 \frac{1}{2}$ miles from the station) and Leswatsi (also called India; Leswatsi was the tribal chief. A small church was erected here, which were used for both services on Sundays and as a school during the week).

These outposts can be seen as testimony that Rev and Mrs AP Burger's dream was fulfilled. This couple of the DRC congregation of Middelburg had a keen interest in mission work, especially in Sekhukhuneland. Mrs Janie Burger, wife of Rev Burger was also one of the pioneers of the TVSV which was established in 1905. She saw this dream fulfilled in the calling of the first missionary and the erecting of the first mission station.

These outposts were established in the pioneering phase of the work. It can also be called the institutional phase: mission work included building a church, a hospital and a school. Other churches also followed the same approach.

The present generation knows very little of the pioneering phase. However, when you talk to the younger generation of the families who were members of these churches and attended these schools, they proudly state that they are now of the third or fourth generation of Christians.

The institutional method of mission work has since been discontinued and has been replaced by an approach that focuses on small congregations or wards. Each is functioning with a church council and women and youth leaders. These small congregations are visited by a minister who has a program for Holy Communion for each of these wards.

In the next section of this article we will see how the Rousseau's son, Kaboet paid tribute to his parents.

\section{Kaboet Rousseau about his father AND MOther}

The author taped an interview with Kaboet, the son of Rousseau, in 1977. He said:

My father started schools at most of the outposts. There were schools in those days, but many of those schools have disappeared. The teachers held services every Sunday. I do not know how my father coped, but at one stage he was working while also holding services at about 60 different places. Most of the places were farms belonging to European farmers, but have since become trust areas. Evangelist Mokoena's wife, Maria, together with my mother, visited many 
NGTT: Oopbron - http://ngtt.journals.ac.za

posts and did a great job. Maria had a good relationship with Dora Mshane, the daughter of kgoši Sekhukhune. She was a believer who openly confessed her salvation in Christ. My father was very disappointed when Dr Le Roux left. The medical work was very important to him. He himself and my mother were very sick with malaria. With the aid of Kgoši Mmutle of Mphahlele the Groothoek medical mission work at Zebediela, was chosen for further development. Situated on the Olifants River, Burger was a very unhealthy place. This was the reason why the mission station was moved to Maandagshoek - (author's own translation).

Kaboet also talked about the small house they occupied at Strydkraal when the family moved from Eensgevonden, and before they settled at Mooiplaats. They did not attend school at Weltevreden anymore, but attended a school at Strydkraal. Kaboet said in the tape recording in 1977 that he and C N Phatudi (a son of the tribal chief at Mphahlele) completed Std VI together. It is not clear what is meant exactly by "together." We know that they wrote Std $\mathrm{VI}$ in the same year and that they were good friends. This is, in any case, an indication of a good relationship between the missionaries and their congregations. Strydkraal is only five kilometres from Mooiplaats. The farms around Strydkraal were bought for the Trust and a beautiful church was built here for the congregation. It was opened in 1953 and he and his mother had the privilege to be present at the opening of this mission church.

Another incident was told by Rev Pierre Joubert, missionary of Seleka congregation when he was scribe for the Presbytery of Kranspoort (probably between 1938 and 1940):

I remember very well the day when I visited Rev and Mrs Rousseau at their mission station at the Olifants River. It was very hot that day and they could not offer me any cool drinking water. Their old refrigerator was out of order for weeks already. I was able to repair it for them and that is why I always remembered them" ${ }^{5}$ (TVSB Ligpunte 1975:31) - (author's own translation).

\section{The Retirement of Rousseau and the inauguration of Rev MJ Louw AND REV EM PHATUdI}

On 27 October 1940 Rousseau retired due to ill health. He accepted a call to Stofberg Theological School in the same year. He died in 1943 (Louw 1955:71). The heritage of Rousseau can be seen in the people who were inspired by him to serve in various occupations. The Nchabeleng brothers provided a list of 15 teachers and the places where they had worked, as evidence of the inspiration that came from Rousseau. All of them helped at the church.

The missionary post remained vacant until the arrival of Rev $L$ van der Merwe in November 1941. He immediately started to attend to the spiritual needs and upliftment of the people. Assisted by Mrs Van der Merwe, Gerrie Jansen and a theological student, Edward Phatudi, he held refresher courses for all the school teachers at a winter camp. Rev van der Merwe only stayed for 13 months, but during that time he succeeded in organizing the congregations, completing the new church building at Mphahlele and registering several schools. Unfortunately he became ill and had to return to Belfast in 1943 (TVSB Ligpunte 1975:19).

The Burger mission station terminated in 1944 and a new phase of mission was started at Maandagshoek (Garatau) by Rev JM Louw and Rev EM Phatudi The inauguration of Rev Louw

\footnotetext{
5 I wrote to the Government of Lebowa in 1977, requesting them to consider transferring Burger back to the church, but this was refused because the parsonage served as a clinic. It was taken over by the army when the new clinic was ready at Strydkraal. Afterwards the buildings were left to deteriorate - author.
} 
NGTT Deel 54, Nommers $3 \& 4$, September en Desember 2013

and Rev Phatudi marked the beginning of the next phase in the mission history of this area, in the sense that Rev Phatudi was a minister on equal footing with Rev Louw. They served different parts of the congregation.

At Maandagshoek a mission hospital was built. New private mission schools were started and the number of evangelists increased to serve the outposts all over Sekhukhuneland. More mission stations, mission hospitals and congregations were established from 1946 (Klipspruit) to 1956 (Goedvertrouwen, the last to be erected). This prepared the way for a partnership on equal footing, when the DRC Mission Church (1932 to 1963), became independent as the "Nederduitse Gereformeerde Kerk in Afrika" (Dutch Reformed Church in Africa) in 1963.

The Nchabeleng brothers remember the inauguration as follows:

The new ministers, MJ Louw and EM Phatudi were inaugurated at Mphahlele and the ceremony was also attended by chief Phatudi. This happened on 27 March 1943. At the inauguration they sang hymns 295 and 388 from the hymn book of Sion. EM Phatudi was the first black minister in the Dutch Mission Church to take office together with a white minister. Rev Phatudi initially stayed in the hostel at Burger Mission. My brother, SM Nchabeleng, who was a teacher at Mohlaletse, stayed at Mothopong and helped the new minister - (author's own translation).

\section{LOOKING BACK ON THE WORK OF ROUSSEAU: WHAT CAN WE LEARN FROM HIS WORK?}

The foundation of the pioneering phase of mission work in Sekhukhuneland was laid by the lay-preachers and those who were converted to Christianity in the Cape Colony or Natal, as well as, for example, Christian mine workers like those at Garatau and the workers of the Zebediela Orange Farm. These workers were from Nyasaland (Malawi) where the DRC Foreign Mission of the Cape already had mission stations going.

The story of Rousseau and his work shows that these believers laid the foundation for the further development of the mission church. They continued to work with Rousseau as his coworkers as co-pioneers: the evangelists, school teachers, hospital staff and other personnel.

Although this was not a partnership on an equal footing, it was however a phase in which such partnership was prepared for. It was not equal in terms of authority, but it was a time where some partners, at least, had mutual respect for each other. They prepared the second phase of mission expansion in Sekhukhuneland.

Can the work of the first phase be described as "integral mission?" The answer is yes, and no. It was integral in the sense that the work was not restricted to the church and a spirituality that is isolated from daily life: churches were built together with schools and hospitals. The different "mainline" churches responded to the needs that they saw, such as sickness and illiteracy, with the resources they had, such as modern health care and education. The children of this era who became teachers later often became active leaders in their congregations too. The pioneers also tried to maintain good relations with the traditional leaders as well as the white government. It appeared later, however, that the pioneering phase was not integral enough. In later years it appeared that the relation between Christian mission and modern Western culture, on the one hand, and traditional African culture, on the other hand, was not as simple 
NGTT: Oopbron - http://ngtt.journals.ac.za

as the pioneers seemed to deal with it, namely to merely align mission with modern Western culture. The schools and hospitals were not permanent features of the church's mission, and new ways have had to be found to be relevant to changing contexts. The relation between mission and the different political forces also became very complex later.

In later years, the partnership between white and black ministers, on equal footing, started to function when the structures of the congregations were designed in such a way that there was a movement away from a hierarchical structure. This structure with the white minister at the top changed to a structure where white and black ministers were on an equal level of authority. The white minister often remained for a period the contact person of the sending body. Through him the funds for the support of his co-workers and many projects like the building of new churches and the maintenance of buildings and other subsidies were channelled. He was responsible for giving a yearly report to the "Plaaslike Sending kommissie" (Local Mission Commission).

The same happened in the congregations of the Presbytery of Burger: they were structured to give white and black ministers equal positions after 1965. Some evangelist posts were replaced by a black minister's post and gradually, after the approval of the phasing out of the evangelists by the General Synod of the (black) Dutch Reformed Church in Africa at Umgababa 1979, evangelists became either ministers or retired. This phase did not last long however: white minister's posts were terminated one after the other from the 1980's onward, and with that also most of the financial support of the DRC. It was the end of Wave Three (Saayman) and the whole mission era of the DRC of the $20^{\text {th }}$ century.

In each phase of mission, the relationships between role players hanged. Willem Saayman named his overview of the Dutch Reformed Mission in South Africa Being missionary, being human. This title shows that the missionaries were ordinary human beings with an extraordinary calling. That was also the case with Rev and Mrs Rousseau. They were children of their time. But they were also missionaries, and as such helped to transform their time and prepare for a new phase in mission, where white and black ministers could work on an equal footing.

Partnership in modern times has changed again. The mission responded to the need of the pioneering phase and provided schools and hospitals. The government followed, and now provides health care and education. New challenges are presented to the church: to help combat poverty and care for orphans of HIV and Aids victims, to search for a sustainable life style, to relate to different religions and ideologies, to find synergy between all these activities. New structures are needed to do so effectively, and these structures are not readily available, as the schools and hospitals were. The challenge is now to develop the necessary structures, if possible, to better serve the emerging vision of the church's mission in our time.

Saayman (2007:139) has formulated it well: he "believe(s) that the next step in the spiritual and missionary journey on which the missionary God wishes to lead the DRC is most probably for them to 'become at ease with daily life and with all that belongs to the human condition' in Africa in the $21^{\text {st }}$ century - and remain to be present to those in need.'That may be the climax of being missionary while being human in Africa."

I can conclude that the pioneer lay-preachers, evangelists and missionaries of the DRC in the pioneering phase, laid the foundation how to c-operate and be a partner in the great commission in the post- $20^{\text {th }}$ century. 


\section{BiBLIOGRAPHY}

Bosch, David J 1994 (8). Transforming Mission New York: Orbis Books.

Crafford, D 1982. Aan God al die Dank. Deel 1. Pretoria: NG Kerk Boekhandel.

Crafford, D 1986. Sendinggeskiedskrywing in SA, in Du Preez, J (ed), Sendinggenade-Feesbundel vir WJ van der Merwe. Bloemfontein: NG Sending Uitgewers, 29 tot 41.

Crafford, D (ed) 1991. Trail Blazers of the Gospel - Black Pioneers in the Missionary History of Southern Africa. University of Pretoria: Institute for Missiological Research (IMR).

Gilomee, Hermann. 2004. Die Afrikaners. 'n Biografie. Kaapstad: Tafelberg.

Jordaan, GJ 2006. Matlala Sending - VGK Lepelle 1956 tot 2006. (Unpublished).

Keet, DJ (ed) 1942. Wonderdade van God - Jubileum Gedenkboek van die Ned Herv of Geref Kerk van Suid-Afrika 1842 tot 1942. Pretoria: Eeufeeskommissie van die Nederduitsche Hervormde of Gereformeerde Kerk van Suid-Afrika.

Louw, LK 1972. Die Sendingarbeid van die NG Kerk in Sekhukhuneland. Fakulteit Teologie (Afd B) van die Universiteit van Pretoria.

Maritz, PNJ. 1977, Juwele van die gemeente-herinnerings uit die veertigjarige-bediening 1920 - 1960. (Unpublished)

Nchabeleng, SM \& Nchabeleng, AL 1993. Report on the history of Mothopong Congregation (Unpublished). Niemandt, Nelus 2011: Trends in ecumenism and mission: 3 significant ecumeni-cal/missional events in 2010.

Rousseau, Kaboet 1977. Tape Recording.

Saayman, Willem 2007: Being Missionary Being Human - an overview of Dutch Reformed Missions. Pietermaritzburg: Cluster Publications.

TVSV - 1935. Verslag van die 27ste Jaarlikse Kongres gehou op Utrecht, 30 November tot 3 Desember 1935. Transvaal Vroue Sendingvereniging, Feesnommer 1905 tot 1930, Sekoekoenieland.

TVSB Ligpunte, November 1975. Derde Jaargang Nr 8. Pretoria: Transvaal Vrouesendingbond.

Van Niekerk, AS 1997: Einde of nuwe begin vir die NG Sending? Ned Geref Teologiese Tydskrif 8:44 Des 1997 pp $408-416$.

Abbreviations:

DRC: Dutch Reformed Church (Nederduits-Gereformeerde Kerk).

TVSV: Transvaal Vroue Sendingvereniging (Transvaal Women's Mission Association).

\section{KEY WORDS}

South African mission history, partnership in mission, integral approach in mission, pioneers in mission, medical mission, mission and education

\section{Trefwoorde}

Suid-Afrikaanse sendinggeskiedenis, sending in vennootskap, integrale benadering in sending, sendingpioniers, mediese sending, sending en onderwys. 
NGTT: Oopbron - http://ngtt.journals.ac.za

\section{Contact Details}

Dr. GJ Jordaan

Dibukeng (VGK boekwinkel)

Office: 0123268737

marindacox@mweb

Posbus 751,

Silverton

0127 